\title{
Alternative Web-Based Assessment and Academic Self-Efficacy of Pre- Service Student Teachers
}

Dina Ahmed Ismaeel, King Faisal University, Saudi Arabia

https://orcid.org/0000-0003-4587-7597

\begin{abstract}
The aim of the present study was to identify the effect of web-based self and peer-assessment approaches on improving pre-service student teachers' academic self-efficacy. In this context, a study was carried out during the second semester of the 2018 academic year among 48 pre-service student teachers enrolled in the Teacher Preparation Program, at the College of Education at King Faisal University. The Academic Self-Efficacy of Alternative Web-Based Assessment survey questionnaire (ASEAWA) was used for the purpose of this study. The results highlighted the value of utilizing self and peer-assessment approaches to enhance pre-service student teacher academic self-efficacy. The study found no significant difference between the influence of web-based self and peer-assessment approaches on academic self-efficacy in terms of the two ASEAWA factors investigated: Academic Achievement and Academic Development. This study has several implications for designers and developers of teacher preparation programs as well as for further research in the field.
\end{abstract}

\section{KEYWORDS}

Academic Self-Efficacy, Alternative Assessment, Peer-Assessment, Pre-Service Teachers, Self-Assessment, Web-Based Learning

\section{INTRODUCTION}

To prepare $21^{\text {st }}$ century teachers, it is necessary to transform existing educational strategies, teaching activities, and evaluation methods in order to prepare teachers to meet the demands of a changing world. Self-efficacy is a $21^{\text {st }}$ century skill that plays a vital role in determining future teachers' success and ability to excel in their profession. Self-efficacy is frequently described in terms of academic self-efficacy, which defines "learner judgments about one's ability to successfully attain educational goals" (Honicke \& Broadbent, 2016, p. 64). Academic self-efficacy influences teachers' beliefs and attitudes, which in turn affect their motivation and ability in terms of teaching, judgment, decisionmaking, assessment, and evaluation, thus impact the quality and standard of activities practiced in the classroom (Manzar-Abbas, Khurshid, \& Rizvi, 2018). "Teachers' beliefs about their ability to teach well influence their students' achievement. These teachers' students become more successful than those of others" (Kahraman, 2014, p. 81).

The potential of assessment, as an essential part of every stage of the learning process, has been stressed by scholars. In recent years, alternative assessment methods have emerged as a nontraditional approach that depends on students' active role in a multidimensional assessment process that determines what they know and can do and, on that basis, evaluates their performance (Tatar \& Buldur, 
2013). Advocates of alternative assessment have noted its positive influence on enhancing students' performance, acquisition of knowledge, and learning skills (Hussein \& Tawfik, 2016; Uto \& Ueno, 2016; Aliasin \& Amanlu, 2017). Alternative assessment is defined as "procedures and techniques which can be used within the context of instruction and can be easily incorporated into the daily activities of the school or classroom" (Aliasin \& Amanlu, 2017, p. 161) in order to measure students' performance and achievement. The potential of assessment, as an essential part of every stage of the learning process, has been stressed by scholars. In recent years, alternative assessment methods have emerged as a nontraditional approach that depends on students' active role in a multidimensional assessment process that determines what they know and can do and, on that basis, evaluates their performance (Tatar \& Buldur, 2013). Advocates of alternative assessment have noted its positive influence on enhancing students' performance, acquisition of knowledge, and learning skills (Hussein \& Tawfik, 2016; Uto \& Ueno, 2016; Aliasin \& Amanlu, 2017). Alternative assessment is defined as "procedures and techniques which can be used within the context of instruction and can be easily incorporated into the daily activities of the school or classroom" (Aliasin \& Amanlu, 2017, p. 161) in order to measure students' performance and achievement.

The relevant literature suggests that alternative assessment practices like self and peer-assessment are important approaches to enhance teachers' self-efficacy (Ören, Ormanci \& Evrekli, 2014; SahinTaskin, 2014; Aliasin \& Amanlu, 2017). Pre-service student teachers through using alternative assessment will identify strengths and weaknesses to support their own learning and teaching process (Van Diggelen, Den Brok \& Beijaard, 2013; Nilsson, 2013). They will have the confidence and competencies necessary to be self-regulated, self-learners, actively engage their students, and continually participate in professional development, which in turn significantly enhance their selfefficacy.

Today, due to the broad utility of web-based learning environments and their various characteristics and tools, which potentially provide great opportunities to design and implement various alternative assessment techniques, students have greater possibilities to evaluate their own performance as well as collaboratively evaluate their peers despite the limitations of time and distance. The use of web-based learning environments and the availability of various tools and techniques is one of the competencies essentially required for pre-service student teachers in temporary education. Pre-service student teachers, in their preparation programs, must be trained on alternative assessment methods using web-based tools and techniques in order to successfully support their future learning and teaching. In the context of Saudi Arabia, alternative web-based assessments like self and peer-assessment are not dominant in higher education programs. Therefore, the present study aimed to assess the influence of two types of alternative web-based assessment methods, self-assessment and peer-assessment, on pre-service student teachers' academic self-efficacy.

\section{LITERATURE REVIEW}

\section{Alternative Web-Based Assessment}

Alternative assessment is advocated in the literature as a new paradigm in education and an essential innovation for the measurement and assessment of learners' performance and progress in various educational settings and contexts (Hussein \& Tawfik, 2016; Iraji, Enayat, \& Momeni, 2016). Alternative assessment methods based on a constructivist approach offer several advantages for learning, such as increasing students responsibility for self-reflection, raising learners' motivation, emphasizing evaluation and discussion skills, and receiving constructive feedback from multiple instructors and peers (Price, Carroll, O’Donovan \& Rust, 2011; Kao, 2013; Uto \& Ueno, 2016).

Self and peer-assessment occupy a significant position among modern alternative assessment approaches. Through self and peer-assessment, in which students assess each other and themselves, students are encouraged to take greater responsibility for their learning by engaging with assessment 
criteria and reflecting on their own performance and that of their peers (Ashraf \& Mahdinezhad, 2015). Several characteristics of self and peer-assessment approaches emphasized in the literature as best suiting the contemporary learner (Elliott, 2008) such as: self-reflection; self-regulation; peer-review; personalized assessment; active engagement; autonomy; flexibility in terms of time, place, content, context, and scope; goal-orientation through a rubric and/or models or examples of exemplary work; enhancing feedback; decision-making, and strengthening judgment skills (Elliott, 2008; Price et al., 2011; Khonbi \& Sadeghi, 2013; Põldoja, Väljataga, Laanpere, \& Tammets, 2014; Zarei \& Usefli, 2015).

The utilization of alternative assessment methods in web-based learning environments is widely applied in the field of education (Cheng, Liang \& Tsai, 2015; Uto \& Ueno, 2016). Several studies in the related literature have indicated the positive impact of web-based self and peer-assessment approaches on improving student performance and learning skills (Leach, 2012; Liu \& Lee, 2013; Ashraf \& Mahdinezhad, 2015; Zarei \& Usefli, 2015; Iraji et al., 2016; McKevitt, 2016).

\section{Academic Self-Efficacy}

Self-efficacy is the fundamental concept of Bandura's (1977) Social Cognitive Theory (Kahraman, 2014). Bandura (1993) defined self-efficacy as "students' beliefs in their efficacy to regulate their own learning, master academic activities and determine their aspirations, level of motivation, and academic accomplishment" (p. 117). A vast body of research has attempted to investigate the relationship between academic self-efficacy beliefs and learners' achievement, performance, and proficiency (Zarei \& Usefli, 2015). Several studies have focused on the strong and positive relationship between academic self-efficacy for learning and subsequent academic performance (Wang \& Wu, 2008; Moos \& Azevedo, 2009; Honicke \& Broadbent, 2016; Hussein \& Tawfik, 2016; Korkmaz, 2016). A metareview of 39 educational studies by Tseng and Tsai (2010) revealed that self-efficacy was strongly correlated with student performance in various educational settings.

Advocates of alternative assessment approaches have promoted their positive and strong impact on raising learner academic self-efficacy as well as the major role they play in learners' ultimate success (Khodarahimi, 2010; Ören, Ormanci \& Evrekli, 2011; Ören, Ormanci \& Evrekli, 2014; Sahin-Taskin, 2014; Aliasin \& Amanlu, 2017). Researchers have defined teacher self-efficacy as "teachers' perceptions of their own competence and their ability to teach as a professional discipline to facilitate students' knowledge, values and behaviors" (Lee \& Tsai, 2010, p. 5). In terms of preservice student teacher preparation programs, there has been a recent increase in the number of studies aiming to explore the self-efficacy of in-service and pre-service student teachers with respect to the use of alternative assessment approaches (Buldur, 2009; Ogan-Bekiroglu, 2009; Güneş, Dilek, Hoplan, Celikoglu \& Demir, 2010; Khodarahimi, 2010; Kahraman, 2014). Such research has revealed high self-efficacy levels in most pre-service student teachers regarding alternative assessment and evaluation approaches (Ören et al., 2011; Ören et al., 2014).

Buldur and Tatar (2011) claimed that the self-efficacy of in-service and pre-service student teachers with regard to using alternative assessment approaches could affect their performance in using these approaches. Therefore, training both in-service and pre-service student teachers on the design and use of alternative assessment strategies was strongly emphasized. Understanding pre-service student teachers' self-efficacy towards the use of alternative assessment leads to the enhancement of pre-service student teachers' knowledge and practice, thereby helping them to become more effective practitioners of alternative assessment strategies in various educational settings (Sahin-Taskin, 2014).

Several studies in the literature have investigated the influence of both self and peer-assessment approaches on self-efficacy beliefs (Kahraman, 2014; Zarei \& Usefli, 2015). A number of studies have indicated a strong and positive correlation between self-assessment methods and an increase of students' self-efficacy (Adediwura, 2012; Baleghizadeh \& Masoun, 2014; Zarei \& Usefli, 2015; Uri \& Aziz, 2017). However, studies by Cassidy (2007) and Kahraman (2014) found no significant relationship between self-assessment and self-efficacy. On the other hand, a study by Tseng and 
Tsai (2010) demonstrated a significant relationship between online peer-assessment and students' self-efficacy and motivation.

In web-based learning environments, which are in the process of expanding and developing, "self-efficacy indicates web users' self-perceived confidence and expectations of utilizing Internet and technology" (Kao \& Tsai, 2009, p. 67). The literature has emphasized the importance of assessing teachers' self-efficacy, particularly in terms of teachers' use of alternative assessment tools in webbased environments (Lee \& Tsai, 2010). Moreover, there is a paucity of studies investigating teacher self-efficacy in relation to their use of alternative assessment tools in web-based environments (Kao \& Tsai, 2009; Lee \& Tsai, 2010). To the best of the author's knowledge, studies measuring the influence of web-based self and peer-assessment methods on pre-service student teachers' self-efficacy are also limited in the related literature. Thus, the significance of the current study has been established.

\section{Aim of the Study}

The present study was conducted to investigate the effect of alternative web-based assessment approaches, both self and peer-assessment, on improving pre-service student teachers' academic selfefficacy. This study also identified which of the two alternative web-based assessment approaches (self or peer) was more influential in raising the level of academic self-efficacy among participants.

\section{Research Questions and Hypotheses}

The current study focused on two research questions. RQ1: Do web-based self and peer-assessment approaches have a positive impact on students' academic self-efficacy? RQ2: Is there any difference in the degree to which web-based self and peer-assessment approaches raise students' level of academic self-efficacy? To answer these two questions, two alternative hypotheses were formulated:

- There are differences that are statistically significant at the 0.05 level between the means of students' pre- and post-tests on the academic self-efficacy scale due to the impact of alternative web-based assessment approaches (self and peer);

- There are differences that are statistically significant at the 0.05 level between the means of students' post-tests on the academic self-efficacy scale due to the impact of alternative web-based assessment approaches (self and peer) that favor the self-assessment approach.

\section{METHODOLOGY}

\section{Participants}

This study used a probability (random) sampling approach, which is a widely used and popular strategy in quantitative studies (Cohen, Manion, \& Morrison, 2002). Participants were pre-service student teachers enrolled in a teacher preparation program at the College of Education at King Faisal University (KFU). The participants were asked to participate in this study in partial fulfillment of their Instructional Technology course. There were two classes in this course: Class 1, with 24 students, and Class 2, also with 24 students. Thus, the total number of students who participated in this study was 48, and all were female students enrolled in the second semester of the 2018 academic year. They were from different majors such as; mathematics, Computer Science, Arabic Language, and Science department. Participants were not familiar with the use of alternative web-based assessment methods, as they do not possess any prior experience regarding self and peer-assessment tools.

\section{Treatment}

The treatment in this study consisted in the application of the two alternative assessment approaches, self-assessment and peer-assessment, using the Self and Peer-Assessment Tool available within the Blackboard Learning Management System (BLMS), in two classrooms comprised of 24 students each. 
As a requirement of the course, through the BLMS, students were assigned to design an educational website using Google Sites; to assist students in completing this assignment, several enriching learning resources were uploaded. Through the educational website design rubric, assessment criteria were explained and discussed with students in class and were uploaded via the Assignment page on BLMS (the rubric is discussed in the Instrument section).

The assessment process for the two research groups was as follow: the self-assessment group was divided into six groups of four students (as shown in Figure 1), and each group was required to complete the assignment by designing an educational website and then uploading it on the BLMS. After that, each group then evaluated itself, gave grades for each of the assessment criteria listed on the self-assessment page, and provided feedback related to their score.

The peer-assessment group was similarly divided into six groups of four (as shown in Figure 1), and each group was required to complete the assignment by designing an educational website and then uploading it on the BLMS. After that, each group evaluated the other five groups (their peers), gave grades for each of the assessment criteria listed on the peer-assessment page, and provided feedback related to their score.

Through the self and peer-assessment tools within the BLMS, each group was able to view their score, on which they were given associated feedback.

Figure 1. Steps for implementing the study treatment
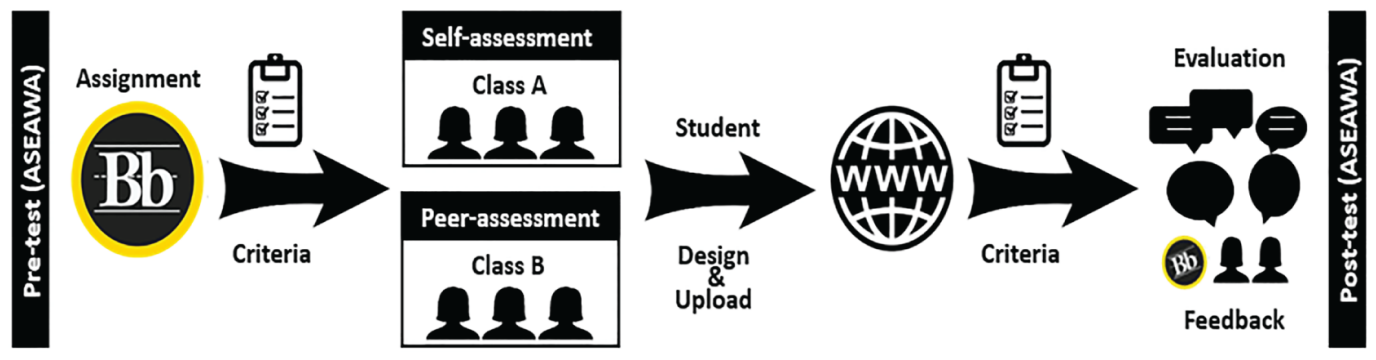

\section{Instruments}

The current study used two instruments.

\section{Academic Self-Efficacy of Alternative Web-Based Assessment Survey Questionnaire (ASEAWA)}

The Academic Self-Efficacy of Alternative Web-Based Assessment survey questionnaire (ASEAWA) was constructed to collect data in the present study. The ASEAWA questionnaire was developed based on a review of the related literature in academic self-efficacy assessment (Baleghizadeh \& Masoun, 2014; Buldur \& Tatar, 2011). The questionnaire instrument consisted of 26 closed-ended statements measuring participants' beliefs in their ability and confidence regarding utilizing alternative assessment tools in web-based learning environments to enhance their academic performance and development. The participants were asked to rate their answers on a 5-point Likert scale: 1 (strongly disagree), 2 (disagree), 3 (neutral), 4 (agree), and 5 (strongly agree).

The validity of the questionnaire was confirmed by seeking the opinion of a group of experts in educational measurement and evaluation regarding how well the instrument statements reflected the instrument subject, the accuracy of the statements, and their appropriateness. The consensus among the experts reflected a high level of approval of the instrument in general. The experts recommended 
reformulating some expressions, deleting others, and supplying new statements, all of which the author carried out.

The reliability of the instrument statements was measured by applying factor analysis using principal axis factoring (PAF) with varimax rotation to the ASEAWA questionnaire completed by a sample of 131 undergraduate pre-service student teachers in the college of education, which was a pilot sample representing the study's population. Cronbach's alpha coefficient was calculated to determine the internal consistency, with a result of 0.863 , which is fairly high according to Field (2013).

As shown in Table 1, the factor analysis produced two conceptual factors, and all 26 of the statements were loaded under these two factors. Only one statement, I think I will have time problems while using web-based alternative assessment tools, with a mean of 3.27, was omitted because it did not load under either of the factors. Factor 1 of the ASEAWA instrument focused on participant's views of their ability and confidence with regard to achieving better learning outcomes using alternative web-based assessment tools; therefore, Factor 1 was named Academic Achievement. It consisted of 18 items. The focus of Factor 2 of the ASEAWA instrument was on participant's views of their ability and confidence with regard to developing their knowledge, values, and technological skills throughout the evaluation process using alternative web-based assessment tools. Therefore, Factor 2 was named Academic Development. It consisted of 8 items, as shown in Table 2.

Table 2 shows the internal correlation coefficients of the two ASEAWA instrument factors. All Factor 1 items were statistically significant $(\mathrm{p}<0.01)$ as were most Factor 2 items $(\mathrm{p}<0.01)$, except for items number 1,2 , and 8 , which were statistically significant at the $\mathrm{p}<0.05$ level. This indicated that all of the ASEAWA instrument statements had reliable internal consistency. The internal correlation coefficients for all instrument items ranged from 0.07 to 0.40 . This indicated that all items of the ASEAWA scale correlated significantly and positively with the total degree of the scale.

\section{Educational Website Design Rubric}

The second instrument was the educational website design rubric in order to evaluate the educational websites, which the students created using Google Sites. The rubric consists of four sections with 27 statements where students are graded according to four levels ranging from $0=$ not accepted; 1 = week; 2 = accepted; and 3 = exemplary. The rubric included four major skills and a number of minor skills related to each skill as following:

1. The skill of creating an educational website, which consists of three skills:

a. Changing the language of the website into Arabic in a way that fits in with its scientific content;

b. The title expresses the content;

c. Simplicity of the website layout and attraction;

2. The skill of creating the educational web pages, which consists three skills:

a. Adding pages to the website, which includes (number of web pages; home page; appropriateness of web pages' title to the content and more than one type of web page e.g. ads page);

b. Website pages content modification, which includes (page's content matches its theme; homepage has a definition of the website and its content; text size is readable; size of the major and minor headings; contain various multimedia; hyperlinks; like buttons);

c. Control of page settings, which includes that every page has at least one attachment and adding comment feature;

3. The skill of formatting the educational website pages, which includes (navigation buttons; website map availability; and side bar);

4. Website administration, which includes three minor skills:

a. Control of the website general layout, which consisted of (Google search engine and mobile compatibility); 
Table 1. Items with varimax rotated factor loadings and reliability coefficients for ASEAWA instrument $(\mathrm{N}=131)$

\begin{tabular}{|c|c|c|c|}
\hline & Factor and Items & Factor 1 & Factor 2 \\
\hline 1 & Through using web-based alternative assessment tools, I can positively interact in class. & 0.684 & \\
\hline 2 & I can acquire new knowledge using web-based alternative assessment tools. & 0.683 & \\
\hline 3 & Classes are more enjoyable using web-based alternative assessment tools. & 0.656 & \\
\hline 4 & $\begin{array}{l}\text { Web-based alternative assessment tools helped me understand the assessment criteria related } \\
\text { to the outputs of the course. }\end{array}$ & 0.629 & \\
\hline 5 & I have positive attitudes towards learning using web-based alternative assessment tools. & 0.611 & \\
\hline 6 & I feel interested in the subject through the use of web-based alternative assessment tools. & 0.596 & \\
\hline 7 & $\begin{array}{l}\text { I can achieve a higher level of academic performance using web-based alternative } \\
\text { assessment tools. }\end{array}$ & 0.582 & \\
\hline 8 & Using web-based alternative assessment tools, I receive the necessary feedback. & 0.564 & \\
\hline 9 & $\begin{array}{l}\text { I can easily turn my acquisitions into grades while using web-based alternative assessment } \\
\text { tools. }\end{array}$ & 0.529 & \\
\hline 10 & I can increase my participation in the class using web-based alternative assessment tools. & 0.522 & \\
\hline 11 & $\begin{array}{l}\text { I can use web-based alternative assessment tools in a way that is suitable to different } \\
\text { educational levels. }\end{array}$ & 0.506 & \\
\hline 12 & $\begin{array}{l}\text { I can determine my attitude towards learning through web-based alternative assessment } \\
\text { tools. }\end{array}$ & 0.505 & \\
\hline 13 & I can use web-based alternative assessment tools in group activities. & 0.481 & \\
\hline 14 & $\begin{array}{l}\text { I can choose web-based alternative assessment tools that are suitable for the content and } \\
\text { educational situations. }\end{array}$ & 0.481 & \\
\hline 15 & I can determine my level of knowledge through web-based alternative assessment tools. & 0.474 & \\
\hline 16 & I think that I will have difficulty while using web-based alternative assessment tools. & 0.473 & \\
\hline 17 & I can explain the importance of web-based alternative assessment tools. & 0.388 & \\
\hline 18 & $\begin{array}{l}\text { I can use different web-based alternative assessment tools suitable for the content and } \\
\text { educational situations (e.g.: portfolio, mental maps, presentations, etc.). }\end{array}$ & 0.380 & \\
\hline 19 & Compared to my classmates, I believe that my level of knowledge is excellent. & & 0.868 \\
\hline 20 & Compared to my classmates, I believe that my level of skills is excellent. & & 0.858 \\
\hline 21 & $\begin{array}{l}\text { Using web-based alternative assessment tools, I can develop deep understanding of the } \\
\text { knowledge acquired. }\end{array}$ & & 0.525 \\
\hline 22 & Using web-based alternative assessment tools, I can acquire new values. & & 0.450 \\
\hline 23 & I can manage the evaluation process through web-based alternative assessment tools. & & 0.410 \\
\hline 24 & I can develop my technological skills using web-based alternative assessment tools. & & 0.349 \\
\hline 25 & $\begin{array}{l}\text { I can utilize technological facilities effectively while using web-based alternative assessment } \\
\text { tools. }\end{array}$ & & 0.344 \\
\hline \multirow[t]{3}{*}{26} & I may have difficulty assessing my skills through web-based alternative assessment tools. & & 0.315 \\
\hline & Cronbach's Alpha & 0.85 & 0.59 \\
\hline & Cronbach's Alpha & 0.863 & \\
\hline
\end{tabular}

b. The share and permission options, which consisted of (website availability and accessibility; edit authorization invitation);

c. The website layout, which consisted of (color and contrast; background and banners design).

To determine the validity of the rubric, group of referees in the field of educational technology were asked to review and give their opinion on the appropriateness and relevance of all statements to the purpose of the rubric, as well as the applicability of the rubric. The results showed a high level 
Table 2. Internal correlation of ASEAWA instrument items ( $\mathrm{N}=131)$

\begin{tabular}{|c|c|c|c|}
\hline \multicolumn{2}{|l|}{ Factor 1: Academic Achievement } & \multicolumn{2}{|c|}{ Factor 2: Academic Development } \\
\hline Items & $\mathbf{R}$ & Items & $\mathbf{R}$ \\
\hline $\begin{array}{l}\text { 1. Through using web-based alternative } \\
\text { assessment tools, I can positively interact } \\
\text { in class. }\end{array}$ & $0.704^{* *}$ & $\begin{array}{l}\text { 1. Compared to my classmates, I believe that } \\
\text { my level of knowledge is excellent. }\end{array}$ & $0.196^{*}$ \\
\hline $\begin{array}{l}\text { 2. I can acquire new knowledge using web- } \\
\text { based alternative assessment tools. }\end{array}$ & $0.625^{* *}$ & $\begin{array}{l}\text { 2. Compared to my classmates, I believe that } \\
\text { my level of skills is excellent. }\end{array}$ & $0.185^{*}$ \\
\hline $\begin{array}{l}\text { 3. Classes are more enjoyable using web- } \\
\text { based alternative assessment tools. }\end{array}$ & $0.662 * *$ & $\begin{array}{l}\text { 3. Using web-based alternative assessment } \\
\text { tools, I can develop deep understanding of the } \\
\text { knowledge acquired. }\end{array}$ & $0.508 * *$ \\
\hline $\begin{array}{l}\text { 4. Web-based alternative assessment tools } \\
\text { helped me understand the assessment criteria } \\
\text { related to the outputs of the course. }\end{array}$ & $0.629 * *$ & $\begin{array}{l}\text { 4. Using web-based alternative assessment } \\
\text { tools, I can acquire new values. }\end{array}$ & $0.454 * *$ \\
\hline $\begin{array}{l}\text { 5. I have positive attitudes towards learning } \\
\text { using web-based alternative assessment tools. }\end{array}$ & $0.584 * *$ & $\begin{array}{l}\text { 5. I can manage the evaluation process } \\
\text { through web-based alternative assessment } \\
\text { tools. }\end{array}$ & $0.599 * *$ \\
\hline $\begin{array}{l}\text { 6. I feel interested in the subject through } \\
\text { the use of web-based alternative assessment } \\
\text { tools. }\end{array}$ & $0.588^{* *}$ & $\begin{array}{l}\text { 6. I can develop my technological skills using } \\
\text { web-based alternative assessment tools. }\end{array}$ & $0.379 * *$ \\
\hline $\begin{array}{l}\text { 7. I can achieve a higher academic } \\
\text { performance using web-based alternative } \\
\text { assessment tools. }\end{array}$ & $0.654^{* *}$ & $\begin{array}{l}\text { 7. I can utilize technological facilities } \\
\text { effectively while using web-based alternative } \\
\text { assessment tools. }\end{array}$ & $0.389 * *$ \\
\hline $\begin{array}{l}\text { 8. Using web-based alternative assessment } \\
\text { tools, I receive the necessary feedback. }\end{array}$ & $0.581 * *$ & $\begin{array}{l}\text { 8. I may have difficulty assessing my skills } \\
\text { through web-based alternative assessment } \\
\text { tools. }\end{array}$ & $0.221^{*}$ \\
\hline $\begin{array}{l}\text { 9. I can easily turn my acquisitions into } \\
\text { grades while using web-based alternative } \\
\text { assessment tools. }\end{array}$ & $0.634 * *$ & & \\
\hline $\begin{array}{l}\text { 10. I can increase my participation in the } \\
\text { class using web-based alternative assessment } \\
\text { tools. }\end{array}$ & $0.642^{* *}$ & & \\
\hline $\begin{array}{l}\text { 11. I can use web-based alternative } \\
\text { assessment tools in a way that is suitable to } \\
\text { different educational levels. }\end{array}$ & $0.577 * *$ & & \\
\hline $\begin{array}{l}\text { 12. I can determine my attitude towards } \\
\text { learning through web-based alternative } \\
\text { assessment tools. }\end{array}$ & $0.587 * *$ & & \\
\hline $\begin{array}{l}\text { 13. I can use web-based alternative } \\
\text { assessment tools in-group activities. }\end{array}$ & $0.494 * *$ & & \\
\hline $\begin{array}{l}\text { 14. I can choose web-based alternative } \\
\text { assessment tools that are suitable for the } \\
\text { content and educational situations. }\end{array}$ & $0.547 * *$ & & \\
\hline $\begin{array}{l}15 . \text { I can determine my level of knowledge } \\
\text { through web-based alternative assessment } \\
\text { tools. }\end{array}$ & $0.479 * *$ & & \\
\hline $\begin{array}{l}\text { 16. I think that I will have difficulty while } \\
\text { using web-based alternative assessment tools. }\end{array}$ & $0.299 * *$ & & \\
\hline $\begin{array}{l}\text { 17. I can explain the importance of web- } \\
\text { based alternative assessment tools. }\end{array}$ & $0.500^{* *}$ & & \\
\hline $\begin{array}{l}\text { 18. I can use different web-based alternative } \\
\text { assessment tools suitable for the content and } \\
\text { educational situations (e.g.: portfolio, mental } \\
\text { maps, presentations, etc.). }\end{array}$ & $0.479 * *$ & & \\
\hline
\end{tabular}

${ }^{* *}$ Correlation is significant at $p<0.01$

${ }^{*}$ Correlation is significant at $p<0.05$ 
of agreement on the applicability of the rubric in general. Some recommendations on rephrasing a number of statements were suggested, and then amendment was performed accordingly to produce the final version of the rubric.

The reliability of the rubric was calculated as well by applying the same rubric on a pilot sample of 10 students studying the same course assessing their educational website design by multiple ratters (two different teachers). The Spearman-Brown coefficient was calculated to determine the correlation between the assessment scores of the two raters. The internal consistency of the assessment rubric was $88 \%$, which is acceptable and is considered a high level of reliability.

\section{Data Collection and Procedures}

For the purpose of the treatment, the study sample was divided into two groups: a self-assessment group and a peer-assessment group. The ASEAWA questionnaire was then distributed to both groups as a pre-test in order to ensure the homogeneity of the groups and to calculate other statistical methods. An introductory lecture with the students was held to provide a concise introduction to the design of the educational website and what they were expected to achieve. An explanation of all the items in the assessment rubric and how students use it in assessing their website design and their peers, were given. A discussion board was allocated for every group, using the BLMS. The students of every group were encouraged to use the discussion board allocated for them to carry out discussions whether among the group members themselves or the members and the teacher. The task of designing an educational website using Google Sites was identified as one main task and provided to the students on the Assignments page on the BLMS within three weeks time plan. All sources of learning of e-books and videos on YouTube on how to use Google Sites to design and produce an educational website were provided on the Course Contents page on the BLMS for all self and peer-assessment groups. The students of each group carry out the task assigned to them to design the educational site, and consult each other on the task and come out with unified results via the discussion board in the BLMS. Through Self and Peer-assessment function on BLMS, each group was able to view the results of the educational websites links they created on Google Sites and then evaluate them and provide feedback. Subsequently, the ASEAWA questionnaire was applied to both groups after the student participants had experienced the study treatment (see Figure 1).

The study implementation took place during the second semester in October 2018. SPSS v.23 was used to conduct the statistical analysis. Descriptive statistical analysis through means, standard deviation, and standard errors of participants' responses were performed for the two factors of the ASEAWA questionnaire. Independent-samples $t$-test was performed in order to allocate the influence of alternative web-based assessment approaches (self and peer) to participants' academic self-efficacy level. In addition, paired-samples $t$-test was performed to measure the statistical differences between the two experimental groups in mean scores regarding the impact of the alternative web-based assessment approaches on their academic self-efficacy. For the $t$-test, the 0.05 alpha level was used as the criterion of statistical significance. The results are discussed in the following section.

\section{RESULTS AND DISCUSSION}

Homogeneity between the groups was calculated by carrying out an independent-samples $t$-test on the pre-test scores for both groups $(\mathrm{t}=1.67, \mathrm{p}>0.05)$. Table 3 presents the means and standard deviations for the self-assessment group $(\mathrm{m}=1.79, \mathrm{SD}=0.59)$ and the peer-assessment group ( $\mathrm{m}$ $=1.56, \mathrm{SD}=0.35$ ).

The $t$-test revealed that there was no statistically significant difference between the treatment groups prior to the treatment application, so homogeneity was found between groups.

The results are discussed in terms of the two research questions of this study as follows: 
Table 3. Independent-samples t-test for both groups' pre-test $(\mathrm{N}=48)$

\begin{tabular}{|c|l|l|l|l|l|}
\hline Group & \multicolumn{1}{|c|}{ M } & \multicolumn{1}{c|}{ SD } & \multicolumn{1}{c|}{ T } & Df & Sig. \\
\hline Self-assessment & 1.79 & 0.59 & 1.67 & 46 & .102 \\
\cline { 1 - 3 } Peer-assessment & 1.56 & 0.35 & & & \\
\hline
\end{tabular}

RQ1: Do web-based self and peer-assessment approaches have a positive impact on students' academic self-efficacy?

To answer this question, an alternative hypothesis was formulated: There should be differences that are statistically significant at the 0.05 level between the means of students' pre-and post-tests on the academic self-efficacy scale due to the impact of alternative web-based assessment approaches (self and peer). Therefore, to test the validity of this hypothesis, a paired-samples $t$-test was performed.

Table 4 presents the paired-samples $t$-test and the descriptive data of the means, standard deviations, and standard errors of the two independent groups (self and peer) in both the pre- and post-tests. The data proves the validity of the first hypothesis of this study as the results indicate statistically significant differences $[\mathrm{m}=56.8, \mathrm{t}(23)=19.382, \mathrm{p}<0.05]$ between students' pre- and post-tests for academic self-efficacy in the self-assessment group. Likewise, there were statistically significant differences $[\mathrm{m}=58.8, \mathrm{t}(23)=28.789, \mathrm{p}<0.05]$ between students' pre- and post-tests of academic self-efficacy in the peer-assessment group. Therefore, generally, the data indicates a significant impact of the application of web-based self and peer-assessment approaches on students' academic self-efficacy. This may be due to how the characteristics of the use of alternative web-based assessment equip students with assessment skills in an objective and reliable manner as well as provide them with the opportunity to develop their skills of criticism, analysis, comparison and judgment, which have a positive effect on their academic self-efficacy skills. These findings are supported by a number of related studies (Leach, 2012; Liu \& Lee, 2013; Ören et al., 2014; Sahin-Taskin, 2014; Ashraf \& Mahdinezhad, 2015; Zarei \& Usefli, 2015; Iraji et al., 2016; McKevitt, 2016; Aliasin, \& Amanlu, 2017).

Table 4. Paired-samples t-test of web academic self-efficacy $(\mathrm{N}=24)$

\begin{tabular}{|c|c|c|c|c|c|c|c|}
\hline \multicolumn{2}{|c|}{ Groups } & $\mathbf{M}$ & SD & SE & $\mathbf{t}$ & Df & Sig. \\
\hline \multirow[t]{2}{*}{ Self } & Pre-test & 1.79 & 0.59 & 0.12 & \multirow[t]{2}{*}{19.382} & \multirow[t]{2}{*}{23} & \multirow[t]{2}{*}{0.000} \\
\hline & Post-test & 3.95 & 0.42 & 0.09 & & & \\
\hline \multirow[t]{2}{*}{ Peer } & Pre-test & 1.56 & 0.35 & 0.07 & \multirow[t]{2}{*}{28.789} & \multirow[t]{2}{*}{23} & \multirow[t]{2}{*}{0.000} \\
\hline & Post-test & 3.82 & 0.27 & 0.05 & & & \\
\hline
\end{tabular}

RQ2: Is there any difference in the degree to which web-based self and peer-assessment approaches raise students' level of academic self-efficacy?

To answer this question, an alternative hypothesis was formulated: There should be differences that are statistically significant at the 0.05 level between the means of students' post-tests in the academic self-efficacy scale due to the impact of alternative web-based assessment approaches (self 
and peer) that favor the self-assessment approach. Therefore, to test the validity of this hypothesis, an independent-samples $t$-test was performed.

Table 5 shows a comparison of the means (with standard deviation and error) for participants' post-test responses for the two alternative web-based assessment approaches, both self and peer, for the two ASEAWA factors. As shown, the mean of the responses of the students treated with the self-assessment approach $(\mathrm{m}=3.86)$ in Factor 1: Academic Achievement was close to the mean of the responses of the students treated with the peer-assessment approach $(\mathrm{m}=3.74)$. Likewise, the mean of the responses of the students treated with the self-assessment approach $(\mathrm{m}=4.15)$ in Factor 2: Academic Development was close to the mean of the responses of the students treated with the peer-assessment approach $(\mathrm{m}=3.99)$.

Table 5. Independent-samples t-test of the two factors of web academic self-efficacy $(N=24)$

\begin{tabular}{|l|c|c|c|c|c|c|c|c|c|}
\hline & \multicolumn{3}{|c|}{ Self } & \multicolumn{7}{c|}{ Peer } & \multicolumn{2}{c|}{} \\
\cline { 2 - 10 } & M & \multicolumn{1}{|c|}{ SD } & SE & M & SD & SE & T & Df & Sig. \\
\hline $\begin{array}{l}\text { Factor 1: } \\
\text { Academic } \\
\text { Achievement }\end{array}$ & 3.86 & 0.46 & 0.09 & 3.74 & 0.32 & 0.07 & 0.989 & 46 & 0.328 \\
\hline $\begin{array}{l}\text { Factor 2: } \\
\text { Academic } \\
\text { Development }\end{array}$ & 4.15 & 0.38 & 0.08 & 3.99 & 0.31 & 0.06 & 1.623 & 46 & 0.112 \\
\hline Sum Factors & 3.95 & 0.42 & 0.09 & 3.82 & 0.27 & 0.05 & 1.262 & 46 & 0.213 \\
\hline
\end{tabular}

To detect if the self and peer-assessment approaches are determining factors in students' academic self-efficacy, an independent-samples $t$-test was calculated. As shown in Table 5, the $t$-test was not significant for either alternative web-based assessment approach in terms of both ASEAWA factors with $\mathrm{t}(46)=0.989, \mathrm{p}>0.05$ for Factor 1 and $\mathrm{t}(46)=1.623, \mathrm{p}>0.05$ for Factor 2 . This indicated that there was no significant difference between the use of the self-assessment approach and the peerassessment approach in terms of increasing the academic self-efficacy in the web-based learning environment. Therefore, the second hypothesis was rejected. This may be due to the nature of webbased alternative assessment characteristics such as privacy, flexibility, and accessibility, which enhance students' active engagement in the evaluation process and therefore facilitate acquiring new and deep knowledge as well as achieving required learning outcomes (Khonbi \& Sadeghi, 2013; Põldoja et al., 2014; Zarei, \& Usefli, 2015). That, in turn, has a positive effect on the level of academic self-efficacy of students treated with the peer-assessment approach as well as with the selfassessment approach. Although a number of studies in the literature conducted in traditional learning environments have indicated that self-assessment approach is as effective in enhancing academic self-efficacy (Adediwura, 2012; Baleghizadeh \& Masoun, 2014; Zarei \& Usefli, 2015; Uri \& Aziz, 2017) as the peer-assessment approach (Tseng \& Tsai, 2010). The result of this study supports the utilization of a web-based environment when designing and delivering both self and peer-assessment approaches. This finding was also indicated by the studies of Kao and Tsai (2009) and Lee and Tsai (2010), which emphasized the importance of assessing teachers' self-efficacy, particularly in terms of teachers' use of alternative assessment tools, in web-based environments.

To investigate the differences between the two ASEAWA factors within each of the two alternative web-based assessment approaches, a paired-samples $t$-test was performed. As shown in Table 6, in the self-assessment approach, the mean of students' responses $(m=4.15)$ in Factor 2: Academic Development was greater than the mean of their responses $(\mathrm{m}=3.86)$ in Factor 1: Academic 
Achievement $[\mathrm{t}(23)=29.034, \mathrm{p}<0.05]$. Likewise, in the peer-assessment approach, the mean of the students' responses $(m=3.99)$ in Factor 2: Academic Development was more than the mean of their responses $(\mathrm{m}=3.74)$ in Factor 1: Academic Achievement $[\mathrm{t}(23)=31.661, \mathrm{p}<0.05]$.

This suggests that student participants' use of alternative assessment tools through web-based environments increased their self-efficacy with regard to academic development more than their self-efficacy with regard to academic achievement. That indicates that students' confidence and competence to engage in developmental practices such as improving technical skills, developing new knowledge and skills, managing evaluation processes, and being able to engage in decision-making based on data-driven processes was improved through the use of web-based assessment tools.

Table 6. Paired-samples t-test of the two factors of web academic self-efficacy $(\mathrm{N}=\mathbf{2 4}$ )

\begin{tabular}{|l|c|c|c|c|c|c|c|c|c|}
\hline & \multicolumn{3}{|c|}{$\begin{array}{c}\text { Factor 1: Academic } \\
\text { Achievement }\end{array}$} & \multicolumn{3}{c|}{$\begin{array}{c}\text { Factor 2: Academic } \\
\text { Development }\end{array}$} & \multicolumn{3}{c|}{} \\
\hline \multicolumn{1}{|c|}{ Groups } & M & SD & SE & M & SD & SE & T & Df & Sig. \\
\hline Self & 3.86 & 0.46 & 0.09 & 4.15 & 0.38 & 0.08 & 29.034 & 23 & 0.000 \\
\hline Peer & 3.74 & 0.32 & 0.08 & 3.99 & 0.31 & 0.06 & 31.661 & 23 & 0.000 \\
\hline
\end{tabular}

\section{CONCLUSION}

The purpose of this study was to investigate the influence of two alternative web-based assessment approaches, self and peer-assessment, on enhancing pre-service student teachers' academic selfefficacy. In addition, the study focused on assessing differences between web-based self and peer-assessment approaches in raising the students' level of academic self-efficacy. The Academic Self-Efficacy of Alternative Web-Based Assessment survey questionnaire (ASEAWA), which was constructed and validated for the purpose of this study, consisted of two factors; Factor 1: Academic Achievement and Factor 2: Academic Development in order to audit participants' beliefs regarding their ability and confidence with regard to the utility of alternative assessment tools in a web-based learning environment.

Generally, the results indicated that pre-service student teachers' academic self-efficacy improved due to the application of both alternative web-based assessment approaches (self and peer). The study also found no significant difference between the use of the web-based self-assessment approach and the peer-assessment approach with regard to increasing the academic self-efficacy in terms of either of the ASEAWA two factors. This demonstrates that the web-based self and peer-assessment approaches both enhanced the pre-service student teachers' ability and confidence to achieve better learning outcomes as well as to develop their knowledge, values, and technological skills throughout the evaluation process. Furthermore, the findings of this study imply that, in both self and the peerassessment approaches, pre-service student teachers were more confident and competent with regard to engaging in developmental practices using the alternative web-based assessment tools than they were in achieving better learning outcomes.

The findings of this study suggest that educators and policy makers who are responsible for designing and developing teacher preparation programs should strongly consider enhancing teachers' personal competencies, particularly academic self-efficacy, throughout the essential preparation processes involving analysis, planning, design, implementation, and, most importantly, evaluation. Utilizing the web-based self and peer-assessment tools recommended by this study as modern and novel evaluation approaches can have a positive impact on reinforcing pre-service student teachers' 
academic self-efficacy and thus enable them to respond to the requirements of modern teaching and learning processes. This distinctive study has implications that call for further research in the focus area to examine the influence of other alternative web-based assessment approaches on academic self-efficacy such as exhibition, demonstration, computer simulations, concept maps, performance evaluation, product assessment and portfolios. In addition, further research to be carried out examining the impact of several characteristics of web-based alternative assessments, such as privacy, flexibility, and accessibility on pre-service student teachers' academic self-efficacy. The association between pre-service academic self-efficacy and the level of their students' motivation in web-based learning environment should be investigated as an implication of this study. Finally, to generalize the results of this study, it is recommended to be conducted on a larger sample of pre-service student teachers from different preparation programs across different universities.

\section{ACKNOWLEDGMENT}

The author acknowledges the Deanship of Scientific Research at King Faisal University for the financial support under Nasher Track (Grant No. 186367). 


\section{REFERENCES}

Adediwura, A. A. (2012). Effect of peer and self-assessment on male and female students' self-efficacy and self-autonomy in the learning of mathematics. Gender \& Behaviour, 10(1), 4492-4508.

Aliasin, S. H., \& Amanlu, M. (2017). The effect of alternative assessment techniques on EFL learners' reading comprehension ability and self-efficacy in reading: The case of Iranian junior high school students. Linguistics and Literature Studies, 5(3), 160-168. doi:10.13189/1ls.2017.050302

Ashraf, H., \& Mahdinezhad, M. (2015). The role of peer-assessment versus self-assessment in promoting autonomy in language use: A case of EFL learners. Iranian Journal of Language Testing, 5(2), 110-120.

Baleghizadeh, S., \& Masoun, A. (2014). The effect of self-assessment on EFL learners' self-efficacy. TESL Canada Journal, 31(1), 42-58. doi:10.18806/tesl.v31i1.1166

Bandura, A. (1977). Self-efficacy: Toward a unifying theory of behavioral change. Psychological Review, 84(2), 191-215. doi:10.1037/0033-295X.84.2.191 PMID:847061

Bandura, A. (1993). Perceived self-efficacy in cognitive development and functioning. Educational Psychologist, 28(2), 117-148. doi:10.1207/s15326985ep2802_3

Buldur, S. (2009) Fen bilgisi öğretmen adaylarının alternatif ölçme ve değerlendirme yaklaşımlarına yönelik okuryazarlık ve öz yeterlik düzeylerinin geliştirilmesi [Developing literacy and self-efficacy levels of science teacher candidates toward alternative assessment approaches]. (Unpublished master's thesis). Cumhuriyet University, Sivas, Turkey.

Buldur, S., \& Tatar, N. (2011). Development of self-efficacy towards using alternative assessment scale. Asia Pacific Education Review, 12(3), 485-495. doi:10.1007/s12564-010-9140-y

Cassidy, S. (2007). Assessing "inexperienced students" ability to self-assess: Exploring links with learning style and academic personal control. Assessment \& Evaluation in Higher Education, 32(3), 313-330. doi:10.1080/02602930600896704

Cheng, K. H., Liang, J. C., \& Tsai, C. C. (2015). Examining the role of feedback messages in undergraduate students' writing performance during an online peer assessment activity. The Internet and Higher Education, 25, 78-84. doi:10.1016/j.iheduc.2015.02.001

Cohen, L., Manion, L., \& Morrison, K. (2002). Research Methods in Education. London: Routledge. doi: $10.4324 / 9780203224342$

Elliott, R. (2008). Assessment 2.0. International Journal of Emerging Technologies in Learning (iJET), 3, 66-70.

Field, A. (2013). Discovering statistics using IBM SPSS statistics. Los Angeles: SAGE.

Güneş, T., Dilek, N. Ş., Hoplan, M., Çelikoğlu, M., \& Demir, E. S. (2010). Öğretmenlerin alternatif değerlendirme konusundaki görüşleri ve yaptıkları uygulamalar [Teachers' opinions on alternative assessment and their applications]. In Proceedings of the International Conference on New Trends in Education and Their Implications (pp.925-935). Academic Press.

Honicke, T., \& Broadbent, J. (2016). The influence of academic self-efficacy on academic performance: A systematic review. Educational Research Review, 17, 63-84. doi:10.1016/j.edurev.2015.11.002

Hussein, A., \& Tawfik, F. (2016). The degree of use of alternative assessment strategies by home economics teachers and the relationship with their female students' self-efficacy in Najran region. Arts and Design Studies, $39,38-52$.

Iraji, H. R., Enayat, M. J., \& Momeni, M. (2016). The effects of self-and peer-assessment on Iranian EFL learners' argumentative writing performance. Theory and Practice in Language Studies, 6(4), 716-722. doi:10.17507/ tpls.0604.08

Kahraman, N. (2014). Investigating the relationship between self-assessment and self-efficacy of pre-service science teachers. International Journal of Education and Research, 2(7), 77-90. 
Kao, C. P., \& Tsai, C. C. (2009). Teachers' attitudes toward web-based professional development, with relation to Internet self-efficacy and beliefs about web-based learning. Computers \& Education, 53(1), 66-73. doi:10.1016/j. compedu.2008.12.019

Kao, G. Y. M. (2013). Enhancing the quality of peer review by reducing student "free riding": Peer assessment with positive interdependence. British Journal of Educational Technology, 44(1), 112-124. doi:10.1111/j.14678535.2011.01278.x

Khodarahimi, S. (2010). General self-efficacy and worry in an Iranian adolescents and youths samples. Educational Research, 1(2), 15-20.

Khonbi, Z. A., \& Sadeghi, K. (2013). The effect of assessment type (self vs. peer) on Iranian university EFL students' course achievement. Procedia: Social and Behavioral Sciences, 70, 1552-1564. doi:10.1016/j. sbspro.2013.01.223

Korkmaz, Ö. (2016). The effects of scratch-based game activities on students' attitudes, self-efficacy and academic achievement. International Journal of Modern Education and Computer Science, 8(1), 16-23. doi:10.5815/ ijmecs.2016.01.03

Leach, L. (2012). Optimal self-assessment: Same tensions and dilemmas. Assessment \& Evaluation in Higher Education, 37(2), 137-147. doi:10.1080/02602938.2010.515013

Lee, M. H., \& Tsai, C. C. (2010). Exploring teachers' perceived self efficacy and technological pedagogical content knowledge with respect to educational use of the World Wide Web. Instructional Science, 38(1), 1-21. doi:10.1007/s11251-008-9075-4

Liu, E. Z. F., \& Lee, C. Y. (2013). Using peer feedback to improve learning via online peer assessment. Turkish Online Journal of Educational Technology, 12(1), 187-199.

Manzar-Abbas, S., Khurshid, M. A., \& Rizvi, S. A. A. (2018). Exploring differences among mentors' and mentees' self-efficacy beliefs at primary level education in China. New Horizons (Baltimore, Md.), 12(1), 23-40.

McKevitt, C. T. (2016). Engaging students with self-assessment and tutor feedback to improve performance and support assessment capacity. Journal of University Teaching \& Learning Practice, 13(1), 1-20.

Moos, D. C., \& Azevedo, R. (2009). Learning with computer-based learning environments: A literature review of computer self-efficacy. Review of Educational Research, 79(2), 576-600. doi:10.3102/0034654308326083

Nilsson, P. (2013). What do we know and where do we go? Formative assessment in developing student teachers' professional learning of teaching science. Teachers and Teaching, 19(2), 188-201. doi:10.1080/13540602.20 13.741838

Ogan-Bekiroglu, F. (2009). Assessing assessment: Examination of pre-service physics teachers' attitudes towards assessment and factors affecting their attitudes. International Journal of Science Education, 31(1), 1-39. doi:10.1080/09500690701630448

Ören, F. S., Ormanci, Ü., \& Evrekli, E. (2011). The science and technology pre-service student teachers' selfefficacy levels and opinions about alternative assessment and evaluation approaches. Educational Sciences: Theory and Practice, 11(3), 1690-1698.

Ören, F. S., Ormanci, Ü., \& Evrekli, E. (2014). The alternative assessment-evaluation approaches preferred by pre-service student teachers and their self-efficacy towards these approaches. Egitim ve Bilim, 39(173), 101-116.

Põldoja, H., Väljataga, T., Laanpere, M., \& Tammets, K. (2014). Web-based self-and peer-assessment of teachers' digital competencies. World Wide Web (Bussum), 17(2), 255-269. doi:10.1007/s11280-012-0176-2

Price, M., Carroll, J., O’Donovan, B., \& Rust, C. (2011). If I was going there I wouldn't start from here: A critical commentary on current assessment practice. Assessment \& Evaluation in Higher Education, 36(4), 479-492. doi:10.1080/02602930903512883

Sahin-Taskin, C. (2014). Pre-service student teachers' self-efficacy for alternative assessment. European Journal of Research on Social Studies, 1(1), 22-26. doi:10.15526/ejrss.201416200

Tatar, N., \& Buldur, S. (2013). Improving preservice science teachers' self-efficacy about the use of alternative assessment. Journal of Baltic Science Education, 12(4), 452-464. 
Tseng, S. C., \& Tsai, C. C. (2010). Taiwan college students' self-efficacy and motivation of learning in online peer assessment environments. The Internet and Higher Education, 13(3), 164-169. doi:10.1016/j.iheduc.2010.01.001

Uri, N. F. M., \& Aziz, M. S. A. (2017). Penilaian Alternatif: Meneroka Keberkesanan Penilaian Kendiri dalam Kalangan Pelajar Jurusan Kejuruteraan [Alternative assessment: Exploring the effectiveness of self-assessment practice among engineering students']. Akademika, 87(1), 141-152. doi:10.17576/akad-2017-8701-10

Uto, M., \& Ueno, M. (2016). Item response theory for peer assessment. IEEE Transactions on Learning Technologies, 9(2), 157-170. doi:10.1109/TLT.2015.2476806

Van Diggelen, M., Den Brok, P., \& Beijaard, D. (2013). Teachers' use of a self-assessment procedure: The role of criteria, standards, feedback and reflection. Teachers and Teaching, 19(2), 115-134. doi:10.1080/1354060 2.2013.741834

Wang, S. L., \& Wu, P. Y. (2008). The role of feedback and self-efficacy on web-based learning: The social cognitive perspective. Computers \& Education, 51(4), 1589-1598. doi:10.1016/j.compedu.2008.03.004

Zarei, A. A., \& Usefli, Z. (2015). The effect of assessment type on EFL learners' goal-orientation. Journal of Language. Linguistics and Literature, 1(4), 112-119.

Dina Ahmed Ismaeel is a Professor of Educational Technology, College of Education, King Faisal University (KFU), P.O.BOX: 400. Al-Ahsa, 31982, Saudi Arabia. Email:dismaeel@kfu.edu.sa. She was the Vice-Head of the Educational Technology Department in the College of Education at KFU. She is a member of the Egyptian Association for Educational Technology (EAET) in Egypt. Her research areas of interest include e-learning, blended learning, multimedia, and virtuality. 